\title{
中国粮食自给率研究 粮食、谷物和口粮自给率分析
}

\author{
杨明智, 裴源生, 李旭东 \\ (中国水利水电科学研究院, 流域水循环模拟与调控国家重点实验室, 北京 100038)
}

\begin{abstract}
摘要: 由于统计口径与计算方法的不同, 粮食自给率的计算结果往往差异较大, 得出的中国粮 食安全的结论也大相径庭, 从而引起国内各界的广泛争议。为了准确分析当前中国的粮食安 全情势, 避免误判对相关决策造成误导, 有必要对粮食的统计口径和自给率计算方法进行分析 研究。本文选用三种粮食自给率计算方法一定额统计法、流向统计法和消费统计法, 测算中国 2000-2016年的粮食、谷物和口粮自给率, 并对结果进行对比分析。结果显示: (1)定额统计法 计算结果容易造成失真, 流向统计法与消费统计法计算结果较为准确; (2)谷物和口粮自给率 更能反映中国实际的粮食供需情况; (3) 中国谷物自给率在 $98 \%$ 以上, 口粮自给率高于 $100 \%$ 。 然而, 随着工业化和城市化进程的加快, 城市发展对土地的需求越来越大, 这会造成耕地被侵 占、粮食需求激增等严重问题, 口粮生产仍然不能放松, 建议未来调整农业结构, 稳定小麦、 稻米生产。
\end{abstract}

关键词: 自给率; 粮食需求; 粮食消费; 粮食库存; 粮食安全

中国是一个农业大国，也是一个人口大国。粮食是关乎国计民生的物质基础，确保 粮食安全对中国具有重要的现实意义。在中国粮食产量连年增长的背景下，党和政府仍 然高度关注当今粮食安全问题。改革开放已经 40 年，中国已进人丰衣足食的社会。然而 粮食危机仍然潜伏着。当前中国的耕地面积已经逼近 18 亿亩红线, 人均耕地面积不足 1.5 亩（1 亩 $=1 / 15 \mathrm{hm}^{2}$ ), 不到世界平均水平的 $50 \%$ 。中国高速的城市化进程使得广大的 农村耕地出现大量荒芜, 粮食增长速度开始减缓。因此, 在全面建成小康社会、实现中 华民族伟大复兴中国梦的关键时期, 要时刻保持粮食安全意识, 决不能因为粮食问题干 扰中华民族复兴的进程。

粮食自给率是衡量国家粮食自给程度、反映国家粮食安全水平的一项重要的评估指 标。中央政府一直高度重视中国粮食自给率问题，国家粮食安全中长期规划纲要（20082020 年）明确提出 “中国粮食自给率要基本保持在 $95 \%$ 以上”。2013 年，中央又提出 “谷物基本自给、口粮绝对安全” 的口号。粮食自给率的准确判定是新时期保障粮食安全 必须谨慎和科学对待的问题。近几年, 众多学者对中国粮食自给率情况进行研究。王更 新 ${ }^{[1}$ 采用定额法分析中国 1980-2003 年中国粮食自给率，认为中国的粮食自给率先升后 降，但还保持在 $95 \%$ 的安全状态以上；尚强民 ${ }^{[2]}$ 分析得出中国粮食自给率已经低于 $90 \%$,

收稿日期：2018-09-27; 修订日期：2019-01-15

基金项目：国家重点研发计划项目（2016YFC0401407）

作者简介：杨明智（1990- ), 男, 安徽毫州人, 博士研究生, 主要从事流域水循环模拟研究。

E-mail: mzyang199006@163.com

通讯作者: 裴源生 (1948- ), 男, 山西灵石人, 教授级高级工程师, 主要从事水资源高效利用和合理配置研究。

E-mail: peiysh@iwhr.com 
而谷物自给率则高于 $100 \%$, 并且保持较高的状态; 郭燕枝等 ${ }^{[3]}$ 分析得出中国的粮食自给 率逼近 95\%, 并认为大豆的进口量剧增导致了粮食自给率和谷物自给率出现明显偏差, 谷物自给率更能反映中国的粮食安全水平; 姜长云等 ${ }^{[4]}$ 研究得出, 自 2009 年以来中国粮 食自给率在不断下降，当前尚处在 $95 \%$ 基本自给线以上，中国粮食安全的基础仍然牢 固; 郭修平 ${ }^{[5]}$ 通过统计中国历年的粮食进出口量来分析中国粮食自给率，认为 2000 年以 来中国的粮食自给率一直处于不断下滑状态，到 2014 年，自给率已经下滑到 $86 \%$ 。由于学 者们采用的粮食统计口径和自给率的计算方法有所不同，所计算的粮食自给率结果也截 然不同。那么中国的粮食自给率情况到底怎样? 这一问题已经引起了广泛的社会争议。

为了反映中国真实的粮食安全情况，避免对政府决策造成误导，对粮食的统计口径 和自给率计算方法进行分析研究十分必要。为此，本文提出了不同于统计口径的自给率 概念，分别称为粮食自给率、谷物自给率和口粮自给率。采用当前常用的三种粮食自给 率计算方法一一定额统计法、流向统计法和消费统计法, 较为全面地考虑了直接消费、 饲料消费、工业消费、进出口、库存、留种等多种粮食消费因素，分别对中国 2000-2016 年的粮食自给率、谷物自给率和口粮自给率进行分析, 并对各方法进行优劣对比, 以期 为国家相关决策提供参考。

\section{1 研究方法与数据来源}

\section{1 数据来源}

采用数据包括中国 2000-2016年粮食（包括小麦、玉米、稻谷等谷类、豆类和薯类） 生产数据，粮食进出口量数据，中国2000-2016年城镇和农村人均食物消费量（包括直接 食用粮、畜禽肉、动物油、水产品、奶制品、酒类等）数据，均来源于《中国统计年 鉴》 ${ }^{[6]}$ 和《中国农村统计年鉴》 ${ }^{[7]}$ 。考虑到数据和资料的可得性，本次仅考虑中国大陆各 省级行政单位，未将中国台湾、香港和澳门地区包括在内。此外，还有中国年末粮食库 存数据来自美国农业部发布的《Grain: World Markets and Trade（2000-2016）》报告 ${ }^{[8]}$ 。

\section{2 计算方法}

根据定义，粮食自给率一般采用粮食总产量 $(G)$ 占总消费需求量 $(D)$ 的百分数 表示。

$$
w=G / D \times 100 \%
$$

式中: $w$ 表示粮食自给率; $G$ 表述粮食总产量; $D$ 表示粮食需求量。

一般地，自给率在 $100 \%$ 以上，就是完全自给；在 $95 \%$ 100\%之间，属于基本自给; 在 $90 \% \sim 95 \%$ 之间，属于可以接受的安全水平; 而自给率小于 $90 \%$, 则表明粮食存在安全 风险。

研究粮食自给率的关键就是粮食统计口径问题和消费需求量的确定问题。不同的粮 食统计口径和需求量计算方法会导致粮食自给率的结果有较大差别。

\section{2 .1 粮食统计口径}

从概念上讲，中国传统意义上的“粮食”（Grain）包括谷物类、豆类和薯类三种， 是广义上的粮食概念。其中，谷物中的大宗品种主要是稻谷、小麦、玉米，另外还有谷 子、高粱等杂粮，但数量较少; 豆类包括大豆、亘豆、绿豆、踠豆、豇豆等品种; 薯类 主要是木薯、红薯、马铃薯等 ${ }^{[3]}$ 。联合国粮食及农业组织的粮食概念仅指 “谷物” (Cere- 
al grain), 属于狭义上的粮食概念, 并不包括豆类和薯类, 而且国际上的粮食自给率参 考值也是按谷物类粮食确定的。可见，国际上的“粮食” 概念与中国并不一致。统计口 径的差别，导致计算结果不同。在本文中，粮食中包括了小麦、大米、玉米、豆类、薯 类和杂粮; 谷物包括小麦、大米、玉米和杂粮; “口粮”（Edible grain）指人们的日常主 食，仅指小麦和大米。

针对不同的粮食统计口径，本文中所计算的自给率分别称为粮食自给率、谷物自给 率和口粮自给率。三种自给率都是常用于评价一个国家或地区粮食安全情况的重要指 标。在历史上, 中国粮食产量不高, 谷类生产不足, 豆类、薯类也是中国部分地区主要 口粮。改革开放以来，随着经济社会的快速发展，农产品供给充足，人民生活水平提 高，消费结构开始多样化，对肉类、蛋、奶、水果等需求也不断上升。居民消费的主粮 已经不再是豆类和薯类，而是以大米、小麦为主的谷物类。因此，谷物和口粮自给程度 对于中国粮食安全状况具有决定性的影响。以谷物自给率和口粮自给率为指标应该可以 较好地反映中国的粮食安全状况。

\subsection{2 消费需求量计算}

粮食消费需求量的计算通常有三种方法：定额统计法、流向统计法和消费统计法。

(1) 定额统计法

定额统计法是最常见的消费需求量估算方法，计算简单，是根据人均年消费量与人 口总数的乘积计算。

$$
D=P \times d
$$

式中： $D$ 为粮食总需求量； $P$ 为总人口; $d$ 为人均需求量。对粮食自给率计算, $d$ 按照参 照《国家粮食安全中长期规划纲要》(2008-2020年) 提供的数据400 kg/(人・a); 对谷物 和口粮自给率的计算, 按照谷物和口粮所占粮食产量比例, $d$ 分别取 $360 \mathrm{~kg} /($ 人 - a) 和 $220 \mathrm{~kg} /($ 人 $\cdot a)$ 。

(2) 流向统计法

流向统计法是一种间接推求粮食需求量的方法。粮食去向可分为粮食消费、粮食出 口、进口和库存四个方面, 粮食需求量可以通过当年粮食产量扣除净出口和库存变化量 得出。由于中国每年的粮食库存量数据对外保密, 本文中的库存量数据来自的美国农业 部报告。

$$
D=G+I-O-\Delta S
$$

式中： $D$ 表示粮食总需求量； $G$ 为粮食总产量； $I$ 表示粮食进口量； $O$ 表示粮食出口量； $\Delta S$ 表示年度粮食库存变化量。

（3）消费统计法

消费统计法是一种直接推求粮食需求量的方法，考虑因素全面，但计算过程复杂。 粮食消费分为直接消费、饲料消费、工业消费、留种及运输储存过程的损耗五种类型。 直接消费就是居民直接食用的粮食消费; 饲料消费, 即转化为居民食用的肉类、禽蛋、 奶等的粮食消费。通过查阅牛、羊、猪、鸡等畜禽饲养标准 ${ }^{[9-13]}$ 得到粮食类饲料结构 (表 1 ), 再结合饲料转化率，求得各类粮食的间接消费量。粮食转化率根据参考文献获 得 ${ }^{[14]}$ 获得: 与牛、羊肉生产转化比 $4.1: 1$, 与猪肉生产转化比 $4.6: 1$, 与动物油生产转化 比 $4.6: 1$, 与禽肉生产转化比 $3.2: 1$, 与命蛋转化比 $3.6: 1$, 与水产品转化比 $2.0: 1$, 与 鲜奶转化比 $0.8: 1$, 与酒类转化比 $0.72: 1$ 。工业用粮是以粮食为原料或辅料进行生产所 
消耗的粮食，比如食品加工、淀粉生 产等。经中国粮食主管部门统计，近 十年来工业用粮量逐年增加，2006 年、2008年、2010年、和 2012 年的工 业用粮量分别为 6800 万 $\mathrm{t} 、 7350$ 万 $\mathrm{t}$ 、 9300 万 $\mathrm{t}$ 和 10130 万 $\mathrm{t}$ ，估算得到中国 工业用粮量年均增长率为 $6.8 \%$ 。工 业用粮中稻谷、小麦、玉米、薯类和

表 1 禽畜的粮食类饲料结构

Table 1 The food forage ingredient of livestock and poultry (\%)

\begin{tabular}{cccccc}
\hline 畜禽类型 & 小麦 & 玉米 & 豆饼 & 谷子 & 马铃薯 \\
\hline 肉牛 & 8 & 69 & 8 & 8 & 8 \\
羊 & 13 & 60 & 13 & 7 & 7 \\
猪 & 10 & 65 & 10 & 5 & 10 \\
奶牛 & 8 & 62 & 15 & 8 & 8 \\
鸡 & 10 & 60 & 10 & 10 & 10 \\
\hline
\end{tabular}
大豆所占比例分别为 $14.04 \% 、 15.23 \% 、 45.79 \% 、 7.40 \%$ 和 $14.40 \%{ }^{[15]}$ ，以此分别计算相应 的粮食种类在每年的工业消耗量。此外，粮食在播种、收割、运输、储存、加工、食用 等环节存在一定比例的无效损耗，为了保证粮食再生产能够正常进行，还要预留一定量的 粮食作为种子粮。参考相关文献，损耗和留种的粮食量取当年总产量的 $5 \%{ }^{[9,15]}$ 。通过加和 五类用粮类型，计算粮食消费需求量。

$$
\begin{gathered}
G_{d}=P_{u} \cdot d_{u}+P_{r} \cdot d_{r} \\
G_{c}=P_{u} \cdot \sum_{i=1}^{9} U_{i} \cdot a_{i}+P_{r} \cdot \sum_{i=1}^{9} R_{i} \cdot a_{i} \\
D=G_{d}+G_{i}+G_{i n}+G_{\text {seed }}+G_{\text {loss }}
\end{gathered}
$$

式中： $D$ 表示消费需求量； $G_{d}$ 表示直接消费量； $G_{c}$ 表示饲料用粮量； $G_{i n}$ 表示工业用粮 量； $G_{\text {sed }}$ 表示预存种子量; $G_{\text {loss }}$ 表示损失量; $P_{u} 、 P_{r}$ 分别表示城镇、农村人口总数; $d_{u} 、 d_{r}$ 分别表示城镇、农村居民人均直接年消费量; $U_{i} 、 R_{i}$ 分别表示城镇、农村居民人均年消 费第 $i$ 种食物的量； $i=1$ (猪肉)、2（牛肉）、3 (羊肉)、4 (动物油)、5 (水产品)、6 (禽肉)、7 (禽蛋)、8 (鲜奶)、9 (酒类)； $a$ 表示粮食转化比。

\section{2 结果分析}

\section{1 粮食自给率}

根据式（1） 式（6）分别计算中国 2000-2016年的粮食自给率，三种方法的计算结 果见图 1 所示。可以看出，采用流向统计法和消费统计法所计算出的结果大致相近; 在 2008 年之后, 采用定额统计法计算出的自给率持续增长, 明显高于另外两种方法所计算 的结果。自 2000 年以来，中国粮食自给率逐年降低，到 2003 年降到了 $85 \%$ 以下。2003年 政府通过提高粮食价格，逐步取消农村税等措施，提高了农民种粮积极性，粮食产量重 新开始了较快增长。图 1 中三条曲线均显示出了先降后升的走势。然而，随着经济社会 的快速发展和人民生活水平不断提高，居民消费结构的多样化，饲料用粮和工业用粮增 加，人民对粮食的需求也大幅增加，粮食进口剧增，当前人均粮食消费量实际上已远超 过 $400 \mathrm{~kg}$ ，粮食自给率也开始出现下滑趋势。可见，定额统计法计算的 2008 年后粮食自 给率已经失真，而流向统计法和消费统计法所计算出的粮食自给率结果较为客观，当前 中国的粮食自给率逼近 $90 \%$ 安全水平。

尽管如此，粮食自给率计算考虑了豆类和著类，其结果并不能反映中国实际的粮食 安全状态。历史上, 中国粮食产量不高, 谷类生产不足, 除了口粮外, 玉米、豆类、薯 类都是中国部分地区的主要口粮。改革开放以来，经济社会的快速发展，农产品供给充 


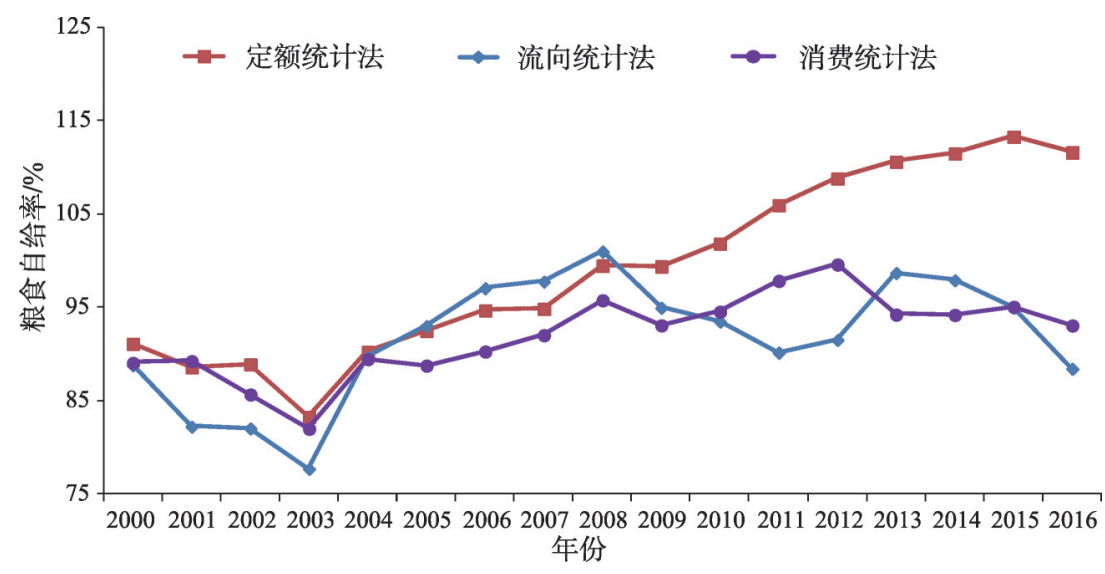

图 1 三种方法计算的中国 2000-2016年粮食自给率走势

Fig. 1 The trends of grain self-sufficiency in China provided by the three methods during 2000-2016

足，人民生活水平不断提高，对肉类、蛋、奶、水果等需求不断上升。豆类和薯类已经 不是主粮，居民消费的粮食是以大米、小麦为主的谷物类。中国加人 WTO 以后，大豆成 为中国进口的大宗农产品，进口量逐年增长，从 2000 年的 1042 万 $\mathrm{t}$ 增加到 2014 年的 7140 万 $\mathrm{t}$, 增加了 $586 \%$ ，占世界大豆总产量的 $23.2 \%$ ，成为世界大豆第一进口国 ${ }^{[16]}$ 。但中国大 豆进口主要用于榨油, 兼用豆粕提供饲料蛋白, 把大豆纳人粮食统计, 实际上夸大了中 国粮食安全问题的严重性。

鉴于以上分析，尽管豆类和薯类占中国粮食产量和消费量的比例都远低于谷物，但 在分析中国粮食自给率时，粮食中是否包括豆类和薯类，对于分析结果和研究结论往往 具有举足轻重的影响，甚至会影响对中国粮食供求平衡方向的判断。谷物和口粮更能反 映中国实际的粮食问题。因此, 研究中国粮食安全问题需要分别对谷物自给率和口粮自 给率做相应的分析研究。

\section{2 谷物自给率}

按照式（1）～式（6），分别计算中国 2000-2016年的谷物自给率，三种方法的计算 结果如图 2 所示。可以看出, 采用流向统计法和消费统计法所计算出的中国谷物自给率 结果比较相近；而2013-2016年这段时间，采用定额统计法计算出的自给率持续增长，明 显高于另外两种方法的结果。采用定额统计法所算出的谷物自给率走向划分为两个阶: 第一阶段为 2000-2008 年，该阶段呈现 “V” 字形，自给率从 89.5\%陡然降落到 80.9\%, 之后又开始回升，到 2008 年超过 100\%；第二阶段为 2009-2016年，呈现连续增长趋势， 到 2016 年增长到 $114.6 \%$ ，远超完全自给水平。流向统计法得出的谷物自给率曲线走势分 为三个阶段，第一阶段为 2000-2006 年，呈现 “V” 字形，自给率从 98.8\%下降到 $90.3 \%$ ，之后开始回升，到 2006 年超过 101\%，达到完全自给；第二阶段为 2007-2010 年，呈现倒 “U” 形，在 2008年达到最高值后开始下降; 第三阶段为 2010-2016年，也呈 现倒 “U”形，但总体上呈现降低趋势，在 2016年下降到 98.5\%，处于基本自给水平。 消费统计法的自给率变化划分为两个阶段（2000-2007年和2008-2016年）：第一阶段呈现 “V” 字形，自给率从 2000 年的 $92.5 \%$ 下降到 $85.7 \%$ ，之后反弹回升，并在 2007 年达到完全 自给; 第二阶段呈现波动增长趋势, 到 2016年，自给率增长到 $103.8 \%$ ，达到完全自给水平。 


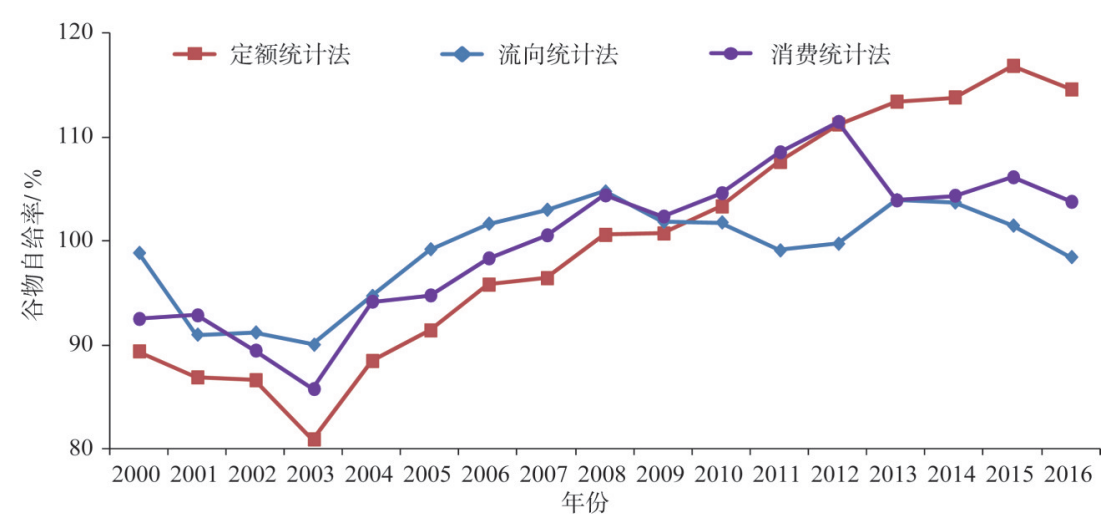

图 2 三种方法计算的中国 2000-2016年谷物自给率走势

Fig. 2 The trends of cereal grain self-sufficiency in China provided by the three methods during 2000-2016

自 2000 年以来，中国谷物产量逐年减少，2003 年降低到 $85 \%$ 以下。自 2004 年开始， 由于中国粮食进出口政策放宽，而且国际粮价降低，中国谷物进口量有了明显增长。为 保证国内粮食安全，保障农民正常生活和收人，提高种粮积极性，国家制定了高于国际 粮价的粮食最低收购价。政策的调整使中国农民种粮积极性提高，谷物产量连年提高， 谷物自给率也随着快速上升。三种方法的计算结果都显示了这一变化过程。由于人民生 活水平的不断提高，对谷物的需求也大幅增加，当前人均消费谷物量应该是逐年增长 的，采用定额法估算的谷物消费量偏低，导致自给率结果偏高。流向统计法与消费统计 法的所计算谷物自给率结果比较相近, 且均显示出中国谷物自给率在波动中出现略微的 下降，应该能客观地反映近几年中国谷物自给率情况。可以判断，当前中国谷物自给率 应该在 $98 \%$ 以上，属于基本自给水平。

\section{3 口粮自给率}

中国居民日常消费的口粮主要是稻米和小麦，计算口粮自给率仅考虑稻米和小麦， 不计玉米等其他谷类。采用定额统计法、流向统计法和消费统计法分别计算中国 20002016 年的口粮自给率，结果如图 3 所示。可以看出，三种方法计算的自给率走势相似， 都呈现了先降后升态势。自 2000 年以来，口粮自给率不断下降，2003 年下降到 $90 \%$ 以 下，之后几年里自给率一度回升超过 100\%。采用定额统计法所算出的口粮自给率到 2006 年超过 $100 \%$ ，之后连续增长，到 2016 年增长到 $110 \%$ 以上，远超完全自给水平; 采用流 向统计法所算出的自给率在 2003 年以后整体呈现上升趋势, 但自 2010 年开始, 受进出口 量的影响，口粮自给率有所下降，到 2012 年低于 $99 \%$ ，但很快回升，到 2016 年达到 $104.8 \%$; 消费统计法计算的自给率在 2003 年以后上升速度很快，在 2005 年就超过了 $100 \%$ ，达到完全自给水平，到 2008 年更是超过 $110 \%$ ，虽然在 2013 年稍有下降，但整体 上处于平稳状态，2016年达到 $114.3 \%$ 。

可以看到，虽然采用不同方法计算的口粮自给率有所不同，但在近十年里，除了个 别年份, 中国口粮自给率都保持在 $100 \%$ 以上, 超过了安全水平线, 属于绝对安全状态。 目前，中国城市化率已经达到了 $57 \%$ ，未来 20 年中国城市化进程仍然会不断推进，城市 人口规模扩大 ${ }^{[17]}$, 未来粮食需求量仍然会继续上升。伴随着城市化的发展，居工地将挤 占农业耕地，统计数据显示中国粮食播种面积正在以每年 $0.65 \%$ 的速率下降 ${ }^{[18]}$, 未来粮食 供给可能会出现较大缺口, 确保粮食生产, 是未来中国粮食安全所面临的重大挑战。因 


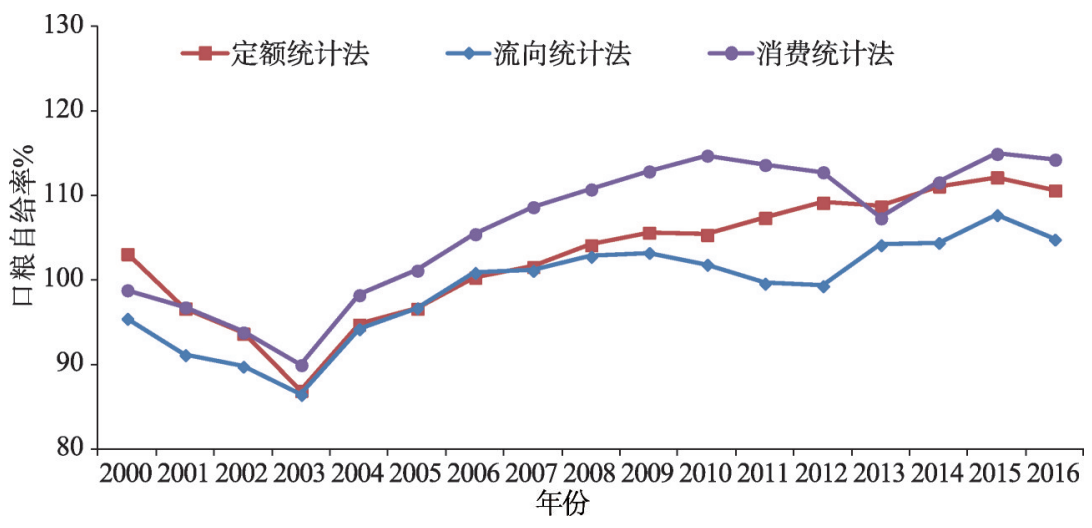

图 3 三种方法计算的中国 2000-2016年谷物自给率走势

Fig. 3 The trends of edible grain self-sufficiency in China provided by the three methods during 2000-2016

此, 中国口粮生产仍不能放松。建议未来调整农业结构, 扩大中国主食作物小麦和稻米 种植面积，而主要用于饲料用途的玉米已经供过于求，应酌情减少播种面积。

\section{3 结论与讨论}

本文通过采用定额统计法、流向统计法和消费统计法三种方法测算并分析中国 2000-2016年的粮食、谷物和口粮自给率情况。通过分析, 得出主要结论如下:

（1）尽管豆类和薯类占中国粮食产量和消费量的比例都远低于谷物，但在分析中国 粮食自给率时，粮食中包括了用于饲料、副食品、酿酒加工等用途的大豆和薯类，影响 了对中国粮食供求平衡方向的判断。谷物自给率和口粮自给率适应了中国发展需求, 更 能反映中国实际的粮食供需问题，应当参照谷物自给率和口粮自给率来制定中国未来的 农业政策。

（2）定额统计法计算简单，但人们对粮食的需求是逐渐增加的，因此，定额统计法 计算粮食自给率容易造成失真; 消费统计法考虑因素众多，但肉粮转化比、工业用粮成 分没有统一标准，此外，由于留种量和损失量没有可靠资料来源，而是采用估计值，这 些都会对结果的准确程度产生一定的影响。尽管如此, 流向统计法与消费统计法所计算 的自给率结果大体上相近, 能客观地反映中国真实的自给率情况。

（3）结果显示，当前中国谷物自给率超过 $98 \%$ ，口粮自给率超过 $100 \%$ ，且都在波动 中缓慢提升。可见，中央提出的 “谷物基本自给，口粮绝对安全” 的目标基本可以达 到。预计未来 20 年中国将继续处于工业化和城镇化高速发展时期, 城市人口数量会呈现 刚性增长, 这就会出现城市外延扩张占用大量耕地, 人口增长导致粮食（特别是小麦、 大米) 需求量剧增等矛盾。中国的小麦、稻米生产仍然不能放松。建议未来调整农业结 构，实施积极的农业政策，稳定小麦、稻米生产。

\section{参考文献(References):}

[1] 王更新. 我国粮食自给率问题研究. 安徽农业科学, 2007, 35(16): 4982-4984. [WANG G X. Study on grain self-sufficient rate in China. Journal of Anhui Agricultural Sciences, 2007, 35(16): 4982-4984.]

[2] 尚强民. 关于粮食自给率的讨论: 兼析粮食供求形势新变化. 中国粮食经济, 2013, (10): 15-18. [SHANG Q M. Discussion on the grain self-sufficiency to analyze the new change of grain supply and demand situation. China Grain Econ- 
omy, 2013, (10): 15-18.]

[3] 郭燕枝, 郭静利, 王秀东. 试比较我国粮食自给率和谷物自给率. 农业经济, 2008, (1): 22-24. [GUO Y Z, GUO J L, WANG X D. Comparison of grain self-sufficiency rate and cereal self-sufficiency rate in China. Agricultural Economy, 2008, (1): 22-24.]

[4] 姜长云, 李显戈, 董欢. 关于我国粮食安全与粮食政策问题的思考: 基于谷物自给率与日、韩相关经验的借鉴. 宏观 经济研究, 2014, (3): 3-10. [JIANG C Y, LI X G, DONG H. Study on the grain security and grain policy in China based on cereal self-sufficiency rate and reference of relevant experience in Japan and Korea. Macroeconomics, 2014, (3): 310.]

[5] 郭修平. 中国粮食自给率波动分析与粮食安全的保障. 中国农机化学报, 2016, 37(5): 258-263. [GUO X P. Analysis on grain self-sufficiency rate and protection of food security in China. Journal of Chinese Agricultural Mechanization, 2016, 37(5): 258-263.]

[6] 国家统计局. 中国统计年鉴. 北京: 中国统计出版社, 2000-2016. [National Bureau of Statistics of the People's Republic of China. China Statistical Yearbook. Beijing: China Statistics Press, 2000-2016.]

[7] 国家统计局, 农村社会经济调查司. 中国农村统计年鉴. 北京: 中国统计出版社, 2000-2016. [Department of Rural Surveys, National Statistics of China. China Rural Statistical Yearbook. Beijing: China Statistics Press, 2000-2016.]

[8] EXPORTS U S R, EXPORTS C V F A. Grain: World markets and trade. Usda Foreign Agricultural Service Gain Report, 2000-2016.

[9] 中华人民共和国农业部. 农业行业标准-肉牛饲养标准 NY/T815-2004. 中华人民共和国农业部, 2004. [The Ministry of Agriculture of the People's Republic of China. Agricultural industry criteria-Feed standard of beef NY/T 815-2004 The Ministry of Agriculture of the People's Republic of China, 2004.]

[10] 中华人民共和国农业部. 农业行业标准-肉羊饲养标准 NY/T816-2004. 中华人民共和国农业部, 2004. [The Ministry of Agriculture of the People's Republic of China. Agricultural industry criteria-Feed standard of sheep NY/T 816-2004. The Ministry of Agriculture of the People's Republic of China, 2004.]

[11] 中华人民共和国农业部. 农业行业标准-猪饲养标准 NY/T65-2004. 中华人民共和国农业部, 2004. [The Ministry of Agriculture of the People's Republic of China. Agricultural industry criteria-Feed standard of pig NY/T 65-2004. The Ministry of Agriculture of the People's Republic of China, 2004.]

[12] 中华人民共和国农业部. 农业行业标准-奶牛饲养标准 NY/T34-2004. 中华人民共和国农业部, 2004. [The Ministry of Agriculture of the People's Republic of China. Agricultural industry criteria-Feed standard of cow NY/T 34-2004. The Ministry of Agriculture of the People's Republic of China, 2004.]

[13] 中华人民共和国农业部. 农业行业标准-鸡饲养标准 NY/T33-2004. 中华人民共和国农业部, 2004. [The Ministry of Agriculture of the People's Republic of China. Agricultural industry criteria-Feed standard of chicken NY/T 33-2004. The Ministry of Agriculture of the People's Republic of China, 2004.]

[14] XU Z, ZHANG W, LI M. China's Grain Production: A Decade of Consecutive Growth or Stagnation?. 2014-05-01. https://monthlyreview.org/2014/05/01/chinas-grain-production/.

[15] 廖永松. 中国到底消费多少粮. 2012-02-27. http://www.zgxcfx.com/Article/42490.html. [LIAO Y S. How much grain is consumed in China?. 2012-02-27. http://www.zgxcfx.com/Article/42490.html.]

[16] 成升鬼, 李云云, 刘晓洁, 等. 关于新时代我国粮食安全观的思考. 自然资源学报, 2018, 33(6): 911-926. [CHENG S K, LI Y Y, LIU X J, et al. Thoughts on food security in China in the new period. Journal of Natural Resources, 2018, 33 (6): 911-926.]

[17] 谢高地, 成升鬼, 肖玉, 等. 新时期中国粮食供需平衡态势及粮食安全观的重构. 自然资源学报, 2017, 32(6): 895903. [XIE G D, CHENG S K, XIAO Y, et al. The balance between grain supply and demand and the reconstruction of China's food security strategy in the new period. Journal of Natural Resources, 2017, 32(6): 895-903.]

[18] 陈香玉. 提高中国粮食自给率的形势分析及政策建议. 安徽农业科学, 2014, 42(35): 12695-12697. [CHENG X Y. Situation analysis and policy recommendations on improving China's grain self-sufficient rate in China. Journal of Anhui Agricultural Sciences, 2014, 42(35): 12695-12697.] 


\title{
Study on grain self-sufficiency rate in China: An analysis of grain, cereal grain and edible grain
}

\author{
YANG Ming-zhi, PEI Yuan-sheng, LI Xu-dong \\ (State Key Laboratory of Simulation and Regulation of Water Cycle in River Basin, China Institute of Water \\ Resources and Hydropower Research, Beijing 100038, China)
}

\begin{abstract}
Due to the difference of statistic standarda and calculation methods, the results of grain self- sufficiency rate were generally quite different and the assessment of the grain security situation in China varied greatly, which aroused great controversy. In order to accurately analyze the grain security situation of China to avoid misleading the relevant decisions, it is necessary to study the grain statistical data sources and the calculation methods of grain self-sufficiency rate. In this work, three commonly used methods, which were the stint counting method, the flow statistics method and the consumption statistics method, were used to estimate and analyze the grain, cereal grain and edible grain self-sufficiency rate in China during 2000-2016. The results were as follows: (1) The stint counting method would cause distortion in the results, while the results provided by the flow statistics method and the consumption statistics method were more accurate. (2) The cereal grain and edible grain selfsufficiency rates could report the actual grain supply demand relations. (3) The self-sufficiency rate of cereal grain was greater than $98 \%$, and that of edible grain was greater than $100 \%$. However, with the acceleration of industrialization and urbanization, city development demand for more land which would cause serious problems such as embezzlement of cultivated land and soaring grain demand, so grain production still should not be slackened in China. It is suggested that the agricultural structure should be adjusted in the future to stabilize the production of wheat and rice.
\end{abstract}

Keywords: self-sufficiency rate; grain demand; grain consumption; grain stock; grain security 